\title{
UPAYA MENINGKATAN KOPETENSI PEDAGOGIK GURU MELALUI SUPERVISI AKADEMIK DI SMP NEGERI 8 KETAPANG
}

\author{
Budi Harto \\ Kepala SMP N 8 Ketapang \\ Email: budiharto6812@gmail.com
}

\begin{abstract}
This research aims to know the proer steps in achieving academic supervision thus being able to improve teacher pedagogical competencies primarily in the learning process that will eventually affect the quality of education. So resarch is done on two cycles. On every cycles has differentplanning, implementation, observation, and reflection. The principal and teacher's research subjects. The principal with his academic supervision act, while the 8 Ketapang public school teacher of the country was both object and subject to the administering of academic supervision. The technique of data collection through class supervision stage in the learning process, to record importand events related to research particularly at the time of the learning process. Research shows that teacher's ability to implement the learning process experiances an increase of percentage per step from cycle I to an average of $63 \%$ (enough) and to cycle II to an average of 68\% (good).there is a 5\% increase in teacher's ability in this cycle I. There is a significant increase in the initial conditions of the school whwn compared with the final conditions of the second cycle II. Teacher punctuality gets into the classroom increases $48 \%$, media utilization increases $32 \%$, variative methods increase $31 \%$, and study strategies increase $36 \%$.
\end{abstract}

\section{Keywords: Pedagogical Competencies, Academic Supervision, and Improved Middle Education Quality (SMP).}

\section{PENDAHULUAN}

Pendidikan merupakan salah satu sektor penting dalam kehidupan manusia, karena pendidikan akan terus ada dan berkembang sepanjang zaman. Pendidikan merupakan suatu proses untuk membantu individu dalam mencapai kedewasaan dan meningkatkan potensi yang dimilikinya sehingga individu tersebut menjadi manusia seutuhnya. Perkembangan Ilmu Pengetahuan dan Teknologi (IPTEK) serta globalisasi komunikasi berdampak pada tuntutan pendidikan yang bermutu yang dapat mengikuti perkembangan IPTEK. Meningkatkan kualitas pendidikan adalah meningkatkan kualitas komponen- komponen sistem pendidikan diantaranya peserta didik, guru dan kepala sekolah. Salah satu faktor yang paling berpengaruh dalam peningkatan mutu pendidikan adalah guru, karena guru berinteraksi secara langsung dengan peserta didik dalam kegiatan pembelajaran. Guru dipandang sebagai faktor kunci.

Peraturan Menteri Pendidikan Nasional Nomor 13 Tahun 2007 tentang Standar Kepala Sekolah/Madrasah menegaskan bahwa seorang kepala sekolah/madrasah harus memiliki lima dimensi kompetensi minimal yaitu: kompetensi kepribadian, manajerial, kewirausahaan, supervisi dan sosial. Permendiknas ini merupakan upaya yang sangat penting untuk menghasilkan kepala sekolah/madrasah yang kuat di dalam mewujudkan kualitas siswa yang diharapkan mampu berpikir kritis, kreatif, inovatif, dan berjiwa kewirausahaan (entrepreneurship). Salah satu tugas kepala sekolah adalah melaksanakan supervisi akademik. Supervisi akademik intinya adalah membina guru dalam meningkatkan mutu proses pembelajaran baik dikelas maupun di luar kelas. Sasaran supervisi akademik adalah guru dalam melaksanakan proses pembelajaran, penyusunan silabus dan RPP, pemilihan strategi/metode/teknik pembelajaran, penggunaan media dan teknologi informasi dalam pembelajaran, menilai proses dan hasil pembelajaran serta penelitian tindakan kelas (Modul Supervisi Akademik, Dirjen PMPTK, 2010). Oleh karena itu, sekolah, sebagai institusi formal yang diharapkan dapat mencetak siswa yang berkualitas, harus dijalankan oleh para pendidik dan tenaga kependidikan yang memiliki 
profesionalisme yang tinggi untuk memajukan sekolah. Berdasarkan kenyataan dari pengamatan selama satu tahun terakhir ini, di SMP Negeri 8 Ketapang, terlihat motivasi dan profesionalisme dari sebagian guru cenderung rendah dalam melaksanakan tugas-tugas mengajarnya.

Hal tersebut dapat dilihat dari absensi kedadiranya sebagai berikut : (1) Hanya 70\% dari guru yang hadir tepat waktu di kelas pada saat jam mengajar; (2) Hanya 50\% dari guru yang memanfaatkan media belajar pada saat mengajar; (3) Hanya 60\% dari guru yang menggunakan metode mengajar secara variatif; (4) Hanya 50\% guru yang menggunakan strategi belajar secara tepat. Selain masalah-masalah di atas, berdasarkan laporan kemajuan pembelajaran triwulan I Tahun Pelajaran 2018/2019 terdapat sekitar 60\% jumlah siswa perkelas, nilainya belum mencapai KKM. Untuk mengatasi masalah di atas, penelitian ini akan melakukan tindakan berupa supervisi akademik, agar motivasi serta profesionalisme guru terutama dalam pengelolaan pembelajaran (kompetensi pedagogik) dapat meningkat dengan baik. Menurut Sullivan dan Glantz (2005) supervisi adalah pembinaan kinerja guru dalam mengelola pembelajaran. Sedangkan menurut Sergiovanni (1987) ada dua tujuan supervisi; pengembangan profesional dan motivasi kerja guru. Melalui Penelitian ini, diharapkan guruguru SMP Negeri 8 Ketapang dapat meningkatkan motivasi serta profesionalis-menya dalam melaksanakan tugas dan fungsi pokoknya terutama pada kompetensi pedagogik (pengelolaan pembelajaran) sehingga dapat meningkatkan mutu pembelajaran di sekolah.

Adapun masalah dalam penelitian ini adalah (1) Bagaimana proses perlaksanaan Supervisi Akademik dalam meningkatkan kompetensi pedagogik guru di SMP Negeri 8 Ketapang ? (2) Apakah penggunaan metode supervisi akademik dapat meningkatkan kemampuan kompetensi pedagogik guru di SMP Negeri 8 Ketapang ?

Berangkat dari masalah, maka tujuan penelitian ini adalah (1) Untuk mendeskripsikan perlaksanaan Supervisi Akademik dalam meningkatkan kompetensi pedagogik guru di SMP Negeri 8 Ketapang. (2) Untuk mengetahui peningkatan kemampuan kompetensi pedagogik guru dengan menggunakan supervisi akademik di SMP Negeri 8 Ketapang.

Manfaat Penelitian ini adalah (1) Bagi Kepala Sekolah : (a) Meningkatkan kinerja kepala sekolah dalam memberikan layanan supervisi pembelajaran terhadap guru. (b) Meningkatkan kualitas kepala sekolah dalam upaya mengembangkan kreatifitas penulisan karya ilmiah. (2) Bagi Guru (a) Meningkatkan kemampuan guru dalam menyusun perangkat Pembelajaran (b) Meningkatkan kualitas pembelajaran dalam kurikulum K13. (3) Bagi Sekolah: (a) Menciptakan inovasi peningkatan kemampuan guru dalam mengembangkan pengetahuan tentang kompetensi pedagogik. (b) Sebagai contoh pembuatan perangkat pe,belajaran untuk guru lainnya.

Definisi Operasional (1) Supervisi akademik. Supervisi akademik adalah serangkaian kegiatan membantu guru mengembangkan kemampuannya mengolah proses pembelajaran untuk mencapai tujuan pembelajaran. Supervisi akademik tidak terlepas dari penilaian kinerja guru dalam mengolah pembelajaran dengan penyususnan RPP. Supervisi merupakan bagian yang tidak terpisahkan dari seluruh proses administrasi pendidikan yang ditujukan terutama untuk mengembangkan efektivitas kinerja personalia sekolah yang berhubungan dengan tugas - tugas utama pendidikan. Supervisi sebagai suatu usaha memberikan layanan kepada guru-guru baik secara individual maupun secara kelompok dalam usaha memperbaiki pengajaran. (2)

Kemampuan Kompetensi Pedagogik Guru kompetensi pedagogik merupakan kemampuan seorang guru dalam mengelola proses pembelajaran yang berhubungan dengan peserta didik, meliputi pemahaman wawasan atau landasan kependidikan, pemahaman terhadap peserta didik, pengembangan kurikulum atau silabus, perancangan pembelajaran, pelaksanaan pembelajaran yang mendidik dan dialogis, pemanfaatan teknologi pembelajaran, evaluasi hasil belajar, dan pengembangan peserta didik untuk mengaktualisasikan berbagai potensi yang dimilikinya. Hipotesis Tindakan Jika kepala sekolah menerapkan supervisi akademik terhadap guru dalam meningkatkan kemampuan diharapakan guru dapat meningkatkan kompetensi pedagogik.

Kompetensi Pegagogik Guru memiliki pengaruh luas dalam dunia pendidikan. Istilah kompetensi memiliki banyak makna. Terdapat beberapa definisi tentang pengertian kompetensi yaitu: (a) Dalam kamus ilmiah populer dikemukakan bahwa kompetensi adalah kecakapan, kewenangan, kekuasaan dan kemampuan.13 (b) Dalam UU RI No 14 tahun 
2005 tentang Guru dan Dosen disebutkan bahwa kompetensi adalah seperangkat pengetahuan, keterampilan dan perilaku yang harus dimiliki, dihayati, dikuasai oleh guru atau dosen dalam melaksanakan tugas keprofesionalan. Dari uraian di atas nampak bahwa kompetensi mengacu pada kemampuan melaksanakan sesuatu yang diperoleh melalui pendidikan. Kompetensi guru menunjuk kepada performance dan perbuatan yang rasional untuk memenuhi spesifikasi tertentu dalam melaksanakan tugas-tugas kependidikan. Hal tersebut dikatakan rasional karena kompetensi mempunyai arah dan tujuan, sedangkan performance adalah perilaku nyata seseorang yang diamati oleh orang lain.

Menurut Gordon sebagaimana yang dikutip oleh E. Mulyasa, bahwa ada enam aspek atau ranah yang terkandung dalam konsep kompetensi, yaitu sebagai berikut : (1) Pengetahuan (knowledge), yaitu kesadaran dalam bidang kognitif, misalnya seorang guru mengetahui cara melakukan identifikasi kebutuhan belajar, dan bagaimana melakukan pembelajaran terhadap peserta didik sesuai dengan kebutuhannya. (2) Pemahaman (understanding), yaitu kedalaman kognitif dan afektif yang dimiliki oleh individu, misalnya seorang guru yang akan melaksanakan pembelajaran harus memiliki pemahaman yang baik tentang karakteristik dan kondisi peserta didik. (3) Kemampuan (skill), adalah sesuatu yang dimiliki oleh individu untuk melakukan tugas atau pekerjaan yang dibebankan kepadanya, misalnya kemampuan guru dalam memilih dan membuat alat peraga sederhana untuk memberikan kemudahan belajar kepada peserta didik. (4) Nilai (value), adalah suatu standar perilaku yang telah diyakini dan secara psikologis telah menyatu dalam diri seseorang, misalnya standar perilaku guru dalam pembelajaran (kejujuran, keterbukaan, demokratis, dan lainlain). (5) Sikap (attitude), yaitu perasaan (senang, tak senang, suka, tidak suka) atau reaksi terhadap suatu rangsangan yang datang dari luar, reaksi terhadap krisis ekonomi, perasaan terhadap kenaikan gaji, dan lain-lain. (6) Minat (interest), adalah kecenderungan seseorang untuk melakukan suatu perbuatan, misalnya minat untuk melakukan sesuatu atau untuk mempelajari sesuatu.

Dari keenam aspek yang terkandung dalam konsep kompetensi di atas, jika ditelaah secara mendalam mencakup empat bidang kompetensi yang pokok bagi seorang guru yaitu kompetensi pedagogik, kompetensi kepribadian, kompetensi sosial, dan kompetensi professional. Keempat jenis kompetensi tersebut harus sepenuhnya dikuasai oleh guru. Kesadaran akan kompetensi juga menuntut tanggungjawab yang berat bagi para guru itu sendiri. Mereka harus berani menghadapi tantangan dalam tugas maupun lingkungannya, yang akan mempengaruhi perkembangan pribadinya. Berarti mereka juga harus berani berubah dan menyempurnakan diri sesuai dengan tuntutan zaman. pedagogik adalah ilmu menuntun anak yang membicarakan masalah atau persoalan-persoalan dalam pendidikan dan kegiatan-kegiatan mendidik, antara lain seperti tujuan pendidikan, alat pendidikan, cara melaksanakan pendidikan, anak didik, pendidik dan sebagainya.

Berdasarkan Undang-Undang No. 14 tahun 2005 tentang Guru dan Dosen dijelaskan bahwa kompetensi pedagogik merupakan kemampuan seorang guru dalam mengelola proses pembelajaran yang berhubungan dengan peserta didik, meliputi pemahaman wawasan atau landasan kependidikan, pemahaman terhadap peserta didik, pengembangan kurikulum atau silabus, perancangan pembelajaran, pelaksanaan pembelajaran yang mendidik dan dialogis, pemanfaatan teknologi pembelajaran, evaluasi hasil belajar, dan pengembangan peserta didik untuk mengaktualisasikan berbagai potensi yang dimilikinya.

Kompetensi pedagogik yang merupakan kemampuan guru dalam pengelolaan pembelajaran peserta didik, menurut E. Mulyasa sekurangkurangnya meliputi hal-hal sebagai berikut: (a) Pemahaman wawasan dan landasan kependidikan Guru sebagai tenaga pendidik yang sekaligus memiliki peran penting dalam upaya meningkatkan mutu pendidikan di negara ini, terlebih dahulu harus mengetahui dan memahami wawasan dan landasan kependidikan sebagai pengetahuan dasar. Pengetahuan awal tentang wawasan dan landasan kependidikan ini dapat diperoleh ketika guru mengambil pendidikan keguruan di perguruan tinggi. (b) Pemahaman terhadap peserta didik Peserta didik adalah setiap orang yang menerima pengaruh dari seseorang atau sekelompok orang yang menjalankan kegiatan pendidikan. Tujuan guru mengenal siswa-siswanya adalah agar guru dapat membantu pertumbuhan dan perkembangannya secara efektif, menentukan materi yang akan diberikan, menggunakan prosedur mengajar yang serasi, mengadakan diagnosis atas kesulitan belajar yang dialami oleh siswa, dan kegiatan-kegiatan guru 
lainnya yang berkaitan dengan individu siswa. (c) Pengembangan kurikulum/silabus Kurikulum adalah seperangkat rencana dan pengaturan mengenai tujuan, isi, dan bahan pembelajaran, serta cara yang digunakan sebagai pedoman pelaksanaan pembelajaran untuk mencapai tujuan pendidikan tertentu. Sedangkan silabus adalah seperangkat rencana dan pengaturan untuk membantu mengembangkan seluruh potensi yang meliputi kemampuan fisik, intelektual, emosional, dan moral agama.

Dalam proses belajar mengajar, kemampuan guru dalam mengembangkan kurikulum/silabus sesuai dengan kebutuhan peserta didik sangat penting, agar pembelajaran dapat berlangsung secara efektif dan menyenangkan. Perancangan pembelajaran Perancangan pembelajaran merupakan salah satu kompetensi pedagogik yang harus dimiliki guru, yang akan tertuju pada pelaksanaan pembelajaran. (e) Pelaksanaan pembelajaran yang mendidik dan dialogis Dalam peraturan pemerintah tentang guru dijelaskan bahwa guru harus memiliki kompetensi untuk melaksanakan pembelajaran yang mendidik dan dialogis. Hal ini berarti bahwa pelaksanaan pembelajaran harus berangkat dari proses dialogis antar sesama subjek pembelajaran sehingga melahirkan pemikiran kritis dan komunikatif. Tanpa komunikasi tidak akan ada pendidikan sejati. (f) Pemanfaatan teknologi pembelajaran Fasilitas pendidikan pada umumnya mencakup sumber belajar, sarana dan prasarana penunjang lainnya, sehingga peningkatan fasilitas pendidikan harus ditekankan pada peningkatan sumber-sumber belajar, baik kualitas maupun kuantitasnya yang sejalan dengan perkembangan teknologi pendidikan dewasa ini. Teknologi pembelajaran merupakan sarana pendukung untuk membantu memudahkan pencapaian tujuan pembelajaran dan pembentukan kompetensi, memudahkan penyajian data, informasi, materi pembelajaran, dan variasi budaya. (g) Evaluasi hasil belajar (EHB) Penilaian Kelas Penilaian kelas dilakukan untuk mengetahui kemajuan dan hasil belajar peserta didik, mendiagnosa kesulitan belajar, memberikan umpan balik, memperbaiki proses pembelajaran dan pembentukan. kompetensi peserta didik serta menentukan kenaikan kelas. Penilaian kelas dilakukan dengan ulangan harian dan ujian akhir. (h) Pengembangan peserta didik untuk mengaktualisasikan berbagai potensi yang dimilikinya. Seiring dengan kemajuan teknologi informasi yang telah demikian pesat, guru tidak lagi hanya bertindak sebagai penyaji informasi tetapi juga harus mampu bertindak sebagai fasilitator, motivator, dan pembimbing yang lebih banyak memberikan kesempatan kepada peserta didik untuk mencari dan mengolah sendiri informasi. Dengan demikian keahlian guru harus terus dikembangkan dan tidak hanya terbatas pada penguasaan prinsip mengajar.

Guru yang baik adalah guru yang selalu bersikap obyektif, terbuka untuk menerima kritik terhadap kelemahan-kelemahan yang ada pada dirinya, misalnya dalam hal caranya mengajar, serta terus mengembangkan pengetahuannya terkait dengan profesinya sebagai pendidik. Kompetensi pedagogik pada penelitian ini hanya terbatas pada kemampuan perancangan pembelajaran, penyelenggaraan pembelajaran yang mendidik dan dialogis, dan evaluasi hasil belajar karena secara operasional ketiga kemampuan tersebut merupakan komponen dalam pengelolaan pembelajaran. Terdidik dan terlatih bukan hanya memperoleh pendidikan formal saja akan tetapi juga harus menguasai berbagai strategi atau teknik di alam kegiatan belajar mengajar serta menguasai landasanlandasan kependidikan seperti yang tercantum dalam kompetensi guru. Kompetensi yang harus dimiliki oleh seorang guru yaitu: kompetensi profesional, kepribadian, pedagogik, dan sosial.

Supervisi Akademik Supervisi adalah suatu aktivitas pembinaan yang direncanakan untuk membantu para guru dan pegawai sekolah lainnya dalam melakukan pekerjaan mereka secara efektif . Sedangkan pengertian supervisi menurut pendapat Hadari Nawawi (1997:99) adalah:" supervisi merupakan suatu kegiatan pengawasan yang dilakukan oleh seorang pejabat terhadap bawahannya untuk melakukan tugas - tugas dan kewajibannya dengan baik sesuai pertelaan tugas yang digariskan".

Supervisi merupakan bagian yang tidak terpisahkan dari seluruh proses administrasi pendidikan yang ditujukan terutama untuk mengembangkan efektivitas kinerja personalia sekolah yang berhubungan dengan tugas - tugas utama pendidikan. Supervisi sebagai suatu usaha memberikan layanan kepada guru-guru baik secara individual maupun secara kelompok dalam usaha memperbaiki pengajaran. Mulyasa (2003: 155). Secara umum supervisi merupakan proses pengembangan organisasi melalui pembinaan yang dilakukan oleh pengawas kepada sekolah, agar kinerja sekolah semakin 
meningkat. Serangkaian kegiatan membantu guru mengembangkan kemampuannya mengelola proses pembelajaran untuk mencapai tujuan pembelajaran. Supervisi akademik merupakan supervisi yang menitik beratkan pada masalah akademik, yaitu langsung berada dalam lingkup kegiatan pembelajaran yang dilakukan oleh guru untuk membantu siswa ketika sedang dalam proses belajar mengajar. Arikunto (2004: 5)

Berdasarkan pendapat di atas dapat disimpulkan bahwa supervisi akademik kepala sekolah merupakan serangkaian bantuan yang diberikan oleh kepala sekolah kepada guru yang menitikberatkan pada aspek kegiatan belajar mengajar yang mana hasil dari pembinaan tersebut akan membantu guru dalam meningkatkan kemampuan profesionalnya dalam mengelola kegiatan belajar mengajar. Dalam Permendiknas No 13 Tahun 2007 disebutkan bahwa kompetensi supervisi kepala sekolah adalah ; a) Merencanakan program supervisi akademik dalam rangka peningkatan profesionalisme guru, b) Melaksanakan supervisi akademik terhadap guru dengan menggunakan pendekatan dan teknik supervisi yang tepat dan c) Menindaklanjuti hasil supervisi akademik terhadap guru dalam rangka peningkatan profesionalisme guru. Dari pernyataan tersebut dapat dijelaskan bahwa tujuan jangka panjang dari supervisi adalah perbaikan pengajaran yang dilakukan oleh guru. Guru merupakan faktor penting dalam proses pelaksanaan pembelajaran, sehingga pengawasan terhadap proses pembelajaran yang dilakukan oleh guru sangat penting agar kompetensi siswa dapat tercapai.

Supervisi akademik adalah serangkaian kegiatan membantu guru mengembangkan kemampuannya mengolah proses pembelajaran untuk mencapai tujuan pembelajaran. Supervisi akademik tidak terlepas dari penilaian kinerja guru dalam mengolah pembelajaran. Refleksi praktis penilaian kinerja guru dalam supervisi akademik adalah melihat kondisi nyata kinerja guru untuk menjawab pertanyaan -pertanyaan misalnya, apa yang sebenarnya terjadi didalam kelas? Apa yang sebenarnya dilakukan oleh guru dan sisiwa didalam kelas? Aktivitas -aktivitas mana dari keseluruhan aktivitas didalam kelas itu yang bermakna bagi guru dan murid ?, apa yang telah dilakukan oleh guru dalam mencapai tujuan akdemik ?, apa kelebihan dan kekurangan guru dan bagaimana cara mengembangkanny. Badan PSDMP (2011: 5)

hal yang perlu ditegaskan disini, bahwa setelah melakukan penilaian kinerja bearti selesailah pelaksannaan supervisi akademik, melainkan harus dilanjutkan dengan tindak lanjutnya berupa pembuatan program supervisi akademik dan melaksannakannya dengan sebaikbaiknya. Tujuan supervisi akademik adalah : Membantu guru mengembangkan kompentensinya. Mengembangkan kurikulum Mengembangkan kelompok kerja guru, dan membimbing penelitian tindakan sekolah (PTS) Supervisi akademik merupakan salah satu (fungsi mendasar (essensial function) dalam keseluruhan program sekolah ). Hasil supervisi akademik berfungsi sebagai sumber informasi bagi pengembangan profesionalisme guru. Badan BSDMP (2011: 6).

Perencanaan merupakan bagian yang sangat penting dalam setiap program, karena kegiatan akan berjalan dengan lancar apabila perencanaanya matang dan sesuai dengan kondisi lembaga. Perencanaan juga harus dipersiapkan dengan baik dalam supervisi akademik yang dilakukan oleh kepala sekolah. perencanaan program supervisi akademik adalah penyusunan dokumen perencanaan kegiatan membantu guru mengembangkan kemampuannya mengelola proses pembelajaran untuk mencapai tujuan pembelajaran. Format-format yang dicontohkan oleh Dirjen PMPTK antara lain : lembar observasi, daftar pertanyaan setelah observasi, hasil observasi, jadwal supervisi kunjungan kelas, rekapitulasi hasil supervisi, instrumen perencanaan kegiatan pembelajaran,instrumen supervisi kunjungan kelas, instrumen observasi peserta didik pada proses pembelajaran, instrumen kunjungan kelas pada proses pembelajaran, instrumen supervisi akademik dengan teknik individual. Imron (2011:232) Perencanaan dalam setiap program memiliki banyak manfaat, begitu pula dalam program supervisi akademik terdapat beberapa manfaat sebagai berikut: (1) Pedoman pelaksanaan dan pengawasan akademik. (2) Untuk menyamakan persepsi seluruh warga sekolah tentang program supervisi akademik. (3) Penjamin penghematan dan keefektifan penggunaan sumber daya sekolah (tenaga, waktu, dan biaya)

Dalam menyusun perencanaan supervisi akademik terdapat prinsip-prinsip perencanaan supervisi akademik adalah sebagai berikut:(1) 
Objektif (data apa adanya) (2) Bertanggungjawab. (3) Berkelanjutan (4) Didasarkan pada Standar Nasional Pendidikan (5) Didasarkan pada kebutuhan dan kondisi sekolah / madrasah.

\section{METODE PENELITIAN}

Penelitian ini merupakan "Penelitian Tindakan" yang dilaksanakan dalam proses kegiatan belajar mengajar. Oleh karena itu, metode yang digunakan adalah Penelitian Tindakan Sekolah (School Action Research) dan peneliti sebagai pelaku tindakan. Penelitian tindakan sekolah adalah penelitian tindakan yang dilakukan dengan tujuan memperbaiki mutu praktik pembelajaran di sekolah, yang berfokus pada pembelajaran di sekolah dan mengenai halhal yang terjadi di sekolah.

Mulyasa (2009: 11) menjelaskan yang dimaksud dengan makalah adalah "suatu upaya untuk mencermati kegiataan belajar sekelompok peserta didik dengan memberikan sebuah tindakan (treatment) yang sengaja dimunculkan". (1) Tempat penelitian Yang menjadi tempat penelitian tindakan sekolah ini adalah SMPN 8 Ketapang. Pemilihan tempat penelitian ini berdasarkan pertimbangan karena sekolah tersebut merupakan sekolah binaan dan pengawasan peneliti. (2) Siklus penelitian PTS ini akan dilaksanakan sebanyak 2 siklus untuk melihat peningkatan aktivitas disiplin masuk sekolah dan administrasi dalam proses belajar mengajar di SMPN 8 Ketapang. (3) Waktu penelitian Makalah ini dilaksanakan pada semester I tahun pelajaran 2019/2020 yaitu mulai tanggal 5 Agustus sampai dengan 16 Agustus 2019 untuk siklus pertama Siklus ke dua di mulai dari tanggal 7 September sampai dengan 19 September 2019. (4) Subjek Penelitian Salah satu ciri penelitian adalah tersedianya subjek penelitian, hal ini tidak jauh berbeda dengan makalah.

Suharsimi Arikunto (2006: 145) menjelaskan yang dimaksud dengan subjek penelitian adalah "subjek yang dituju untuk diteliti oleh peneliti", dan yang menjadi subyek penelitian dalam makalah ini adalah sekolah SMPN 8 Ketapang. (5) Teknik dan Alat Pengumpul Data (a) Teknik Pengumpul Data Pengumpulan data dilakukan untuk memperoleh informasi yang dibutuhkan dalam rangka mencapai tujuan penelitian. Dalam membahas masalah teknik penelitian, terdapat beberapa teknik dan penggunaan salah satu atau beberapa tehnik sekaligus dalam sebuah penelitian juga dapat dimungkinkan. Sebagai acuan dalam memilih teknik penelitian mana yang akan digunakan, maka Hadari Nawawi (2007: 100) menyebutkan beberapa teknik yaitu " (1) Teknik observasi langsung, (2) Teknik observasi tidak langsung, (3) Teknik komunikasi langsung, (4) Teknik komunikasi tidak langsung, (5) Teknik pengukuran, dan (6) Teknik studi dokumenter".

Teknik pengumpulan data yang digunakan adalah teknik observasi langsung, teknik observasi tidak langsung, dan teknik komunikasi langsung. yaitu cara pengumpulan data yang dilakukan dengan mengadakan hubungan secara langsung dan tidak langsung atau dengan menggunakan perantaraan a1 at, baik berupa alat yang sudah tersedia maupun alat khusus yang dibuat untuk keperluan pengumpulan data. (b) Alat Pengumpul Data (1) Observasi Dalam suatu penelitian, peneliti paling sering menggunakan alat pengumpul data berupa observasi. Observasi merupakan cara pengumpulan data dengan cara mengamati. W. Gulo (2007: 116) menjelaskan "observasi adalah metode pengumpulan data dimana peneliti atau kolabotornya mencatat informasi sebagaimana yang mereka saksikan selama penelitian". (2) Angket Alat yang digunakan dalam pengumpulan data untuk teknik komunikasi tidak langsung adalah angket. Zainal Arifin (2009: 166) menjelaskan "Angket termasuk alat untuk mengumpulkan dan mencatat data atau informasi, pendapat, dan faham dalam hubungan kausal". Jadi angket merupakan suatu alat yang dapat digunakan untuk mengumpulkan data atau informasi.

\section{HASIL DAN PEMBAHASAN PENELITIAN Kondisi Sekolah}

Berdasarkan pengamatan selama satu tahun terakhir baik secara kualitatif dan kuantitatif, terlihat motivasi dan profesionalisme dari sebagian guru cenderung rendah dalam tugastugas mengajar. Hal tersebut dapat dinilai dari hal-hal sebagai berikut: (1) Hanya 40\% dari guru yang menggunakan strategi belajar secara tepat; (2) Hanya $60 \%$ dari guru yang hadir tepat waktu di kelas pada saat jam mengajar; (3) Hanya 50\% dari guru yang keluar tepat waktu sesuai jadwal mengajar; (4) Hanya $40 \%$ dari guru yang memanfaatkan media belajar pada saat mengajar; (5) Hanya 50\% dari guru yang menggunakan metode mengajar secara variatif. Selain masalahmasalah di atas, berdasarkan laporan kemajuan pembelajaran triwulan I Tahun Pelajaran 
2017/2018 terdapat sekitar 50\% jumlah siswa perkelas, nilainya belum mencapai KKM.

\section{Hasil Peneltian}

\section{(1) Kegiatan Siklus 1}

(a) Perencanaan Pada tahap perencanaan dilakukan sosialiasi tujuan dan ruang lingkup penelitian kepada guru. Penjelasan fokus penelitian tentang Supervisi Akademik. (b) Pelaksanaan Pada Pertemuan awal, peneliti mengumpulkan seluruh guru. Menjelaskan maksud dan tujuan Penelitian Tindakan Sekolah Penjelasan tentang kompetensi pedagogik guru difokuskan pada perbaikan komponen proses pembelajaran. Berikut pula penjelasan tentang aspek yang akan diamati melalui deskriptor setara. Tanya jawab tentang segala sesuatu yang berkaitan dengan penelitian. (c) Observasi Pada tahap ini seorang guru melakukan pembelajaran sesuai dengan aspek dan deskriptor yang telah dijelaskan sebelumnya, penulis dan PKS kurikulum melakukan supervisi kelas dengan menggunakan lembar observasi yang telah disiapkan. Ada beberapa orang guru yang merasa belum siap dan keberatan untuk menyiapkan proses pembelajaran yang memenuhi aspek dan deskriptor hanya dalam jangka waktu 1 (satu) minggu, tetapi setelah diberikan penjelasan mereka dapat mengikuti dan memahami tujuan penelitian. (d) Tahapan Refleksi Pada awal siklus ini, hasil observasi peneliti yang dibantu oleh kolega diperoleh gambaran bahwa hasil siklus I total skor terendah $61 \%$ artinya bahwa tingkat pelaksanaan proses pembelajaran cukup dan skor tertinggi $70 \%$ artinya berada pada interpretasi baik dan hasil persentase rata-rata dari seluruh guru yaitu 63\% (cukup) .

(2) Kegiatan Siklus 2 (a) Perencanaan Menginformasikan kepada guru tentang hasil siklus I. Menyampaikan hasil observasi proses pembelajaran melalui deskriptor yang telah muncul. Mengadakan Tanya jawab tentang kelemahan proses pembelajaran yang telah terjadi. (b) Pelaksanaan Menginformasikan kepada guru, tentang kesesuaian dan kemajuan (progress) hasil observasi. Mengadakan diskusi tentang hal-hal yang berkaitan dengan pelaksanaan proses pembelajaran, jika masih ada yang belum dipahami. Mengumpulkan dokumendokumen penilaian supervisi kunjungan kelas. (c) Observasi Penulis melakukan pengamatan sesuai rencana dengan menggunakan lembar observasi terutama pada aspek dan deskriptor yang belum muncul pada siklus I. Pada siklus II ini akan dilihat apakah deskriptor yang telah muncul pada siklus I dapat secara konsisten muncul kembali pada siklus II disertai dengan penambahan deskriptor yang belum muncul sebelumnya. (c) Tahapan Refleksi Pada Siklus II didapatkan hasil sebagaimana tertera pada tabel 4.3 dengan hasil pengamatan penulis pada siklus II sebagai berikut : Terjadi peningkatan prosentase tingkat kesesuaian, skor terendah 65\% (interpretasi cukup ), dan skor tertinggi $80 \%$ (interpretasi Baik) jika dibandingkan dengan siklus I, dengan rata-rata 68\% (interpretasi Baik). Dari hasil tersebut dapat disimpulkan bahwa terjadi peningkatan pemahaman guru dalam kompetensi pedagogik yang dimiliki dimulai dari perubahan penyiapan kelengkapan perangkat pembelajaran, cara berinteraksi dengan peserta didik cara menciptakan metode dan strategi belajar yang menarik. (c) Pembahasan Berdasarkan hasil penelitian dari siklus I dan siklus II terdapat peningkatan kemampuan kompetensi pedagogik guru di SMP Negeri 8 Ketapang hal ini dapat terlihat pada tabel peningkatan pada kategori pelaksanaan perangkat pembelajaran sebagai berikut:

Tabel 1. Peningkatan Hasil Siklus I dan Siklus II

\begin{tabular}{cccc}
\hline No. & Uraian Kondisi & $\begin{array}{c}\text { Ketercapaian } \\
\text { Siklus I (\%) }\end{array}$ & Ketercapaian Keadaan (Siklus II $)$ \\
\hline 1. & Masuk tepat waktu di kelas & 50 & 98 \\
\hline 2. & Pemanfaatan media belajar & 30 & 62 \\
\hline 3. & Metode variatif & 40 & 71 \\
\hline 4. & Strategi belajar & 20 & 56 \\
\hline
\end{tabular}

Dari hasil diatas terlihat jelas terdapat peningkatan kemampuan kompetensi pedagogik guru di SMP Negeri 8 Ketapang. Hal ini disebabkan oleh adanya penerapan dan perlaksanaan supervisi akademik yang dilakukan oleh kepala sekolah serta bimbingan tentang peningkatan kemampuan kompetensi pedagogik terhadap guru guna meningkatkan kualitas belajar 
mengajar dan proses pembelajaran serta interaksi dengan perserta didik. Dari hal tersebut supervisi akademik sangat berpengaruh dan sangat dibutuhkan oleh setiap guru karena dengan melakukan supervisi akademik sebagai bantuan pengembangan situasi belajar mengajar agar lebih baik. Sebagai pelayanan khususnya menyangkut perbaikan proses belajar mengajar dan supervisi sebagai pembinaan yang diberikan kepada seluruh staf sekolah dan meningkatkan kemampuan untuk mengembangkan situasi belajar mengajar yang lebih baik. Situasi belajar inilah yang seharusnya diperbaiki dan ditingkatkan melalui layanan kegiatan supervisi.

Dengan demikian layanan supervisi tersebut mencakup seluruh aspek dari penyelenggaraan pendidikan dan pengajaran. Peningkatan kompetensi guru dapat dilaksanakan melalui berbagai strategi dalam bentuk pendidikan dan pelatihan. Hal ini dimungkin kan karena adanya kerja sama yang baik antara kepala sekolah sebagai supervisor dengan para guru tersebut, yang didukung oleh adanya motivasi dan bimbingan dari kepala sekolah sehingga para guru memiliki antusiasme yang besar untuk dapat meningkatkan kemampuan mereka masingmasing. Kompetensi guru merupakan seperangkat pengetahuan, keterampilan, dan prilaku yang harus dimiliki, dihayati, dikuasai, dan diaktualisasikan oleh guru dalam melaksanakan tugas utamanya. Pemahaman tentang peserta didik meliputi pemahaman tentang psikologi perkembangan anak, sedangkan pembelajaran yang mendidik meliputi kemampuan guru dalam merancang pembelajaran, melaksanakan pembelajaran, menilai proses dan hasil pembelajaran, dan melakukan perbaikan secara berkelanjutan.

Guru sebagai desainer atau perancang pembelajaran berkaitan dengan kompetensi pedagogiknya yang harus mampu mendesain pembelajaran dengan baik. Rancangan pembelajaran harus dimulai dengan memastikan bahwa suatu rancangan pembelajaran cocok untuk program atau rencana pelaksanaan pembelajaran yang akan dilaksanakan. Oleh karena itu, seorang guru harus tahu perkiraanperkiraan akan kebutuhan belajar yang dibutuhkan siswa dan dapat dijadikan sebagai informasi awal untuk menyusun atau merancang persiapan pembelajaran dan melaksanakan pembelajaran yang efektif. Salah satu hal yang menjadi tantangan adalah masalah penerapan kompetensi pedagogik yang dimiliki guru saat proses pembelajaran. Persoalan ini dirasakan sulit karena apabila proses pembelajaran tidak sesuai dengan kompetensi pedagogik yang dimiliki maka pembelajaran tidak akan membawa perubahan yang baik bagi peserta didik. Guru dalam proses belajar mengajar di sekolah perlu menciptakan suasana belajar yang menarik dan menyenangkan, dinamis namun terarah dalam mencpai tujuan pembelajaraan sesuai dengan kompetensi pedagogik yang dimiliki guru.

\section{SIMPULAN DAN SARAN Simpulan}

Berdasarkan hasil penelitian yang diperoleh melalui penggunaan supervisi akademik untuk peningkatan kemampuan kompetensi pedagogik guru pada siklus I dan siklus II: (1) Proses pelaksanaan supervisi akademik pada guru diSMP Negeri 8 Ketapang diawali dengan memberikan bimbingan dan arahan serta penilaian pada siklus 1 dan siklus 2 guna meningkatkan kemampuan kompetensi pedagogik guru dengan mengikuti tahapan-tahapan supervisi akademik yang telah terlampir didalam pelaksanaan kegiatan penerapan proses belajar mengajar didapat hasil yang berbeda dengan kegiatan mengajar pada hari sebelumnya maka dapat disimpulkan terdapat peningkatan kemampuan kompetensi pedagogik guru dalam meningkatkan kualitas pembelajaran. (2) supervisi akademik dapat meningkatkan kemampuan kompetensi pedagogik guru hal ini didasarkan pada hasil siklus I dan siklus II. Pada siklus I tidak terjadi peningkatan yang maksimal sedangkan pada siklus II didapat hasil peningkatan yang baik, hal ini terjadi karena adanya bimbingan dari supervisor dalam hal ini adalah kepala sekolah melalui kegiatan supervisi akademik. Kegiatan supervisi akademik dilakukan secara intensif dan berkesinambungan dapat meningkatkan kompetensi guru dalam meningkatkan mutu proses pembelajaran yang terdiri dari materi pokok dalam proses pembelajaran, penyusunan silabus dan RPP, pemilihan strategi, metode, model, teknik pembelajaran, penggunaan media dan teknologi informasi dalam pembelajaran, menilai proses dan hasil pembelajaran serta pengolahan kegiatan belajar mengajar dikelas.

\section{DAFTAR PUSTAKA}

Arikunto,Suharsimi.2009. Dasar-Dasar Evaluasi Pendidikan.Jakarta : Bumi Aksara. 
Mulyasa. (2003). Menjadi Kepala Sekolah Profesional. Remaja Rosda Karya : Bandung.

Mukhtar dan Iskandar.2009. Orientasi Supervisi Pendidikan. Jakarta : GPP Press.

Nawawi, Hadari.2006.Kepemimpinan Mengefektifkan Organsiasi.Yogyakarta : Gadjah Mada University Press.

Undang-Undang Guru dan Dosen Nomor 14 Tahun 2005, Jakarta: Kementerian Hukum dan HAM.

Peraturan Pemerintah Nomor 74 Tahun 2008 tentang Guru. Jakarta : Depdiknas.
PMPTK, Dirjen, Materi Supervisi Akademik Penguatan Kepala Sekolah dan Pengawas, Jakarta: 2010.

Pidarta,Made.2009. Supervisi Pendidikan Kontekstual. Jakarta : Rineka Cipta

Purwanto, M. Ngalim. 1987.Prinsip-prinsip dan Teknik Evaluasi Pengajaran. Bandung : Remaja Rosdakarya.

Riduwan.2007. Belajar Mudah Penelitian Untuk Guru-karyawan dan peneliti muda,Bandung : Alfabeta.

Syaiful Mustofa. (2013). Supervisi Pendidikan (Terobosan baru dalam peningkatan kerja pengawas sekolah dan guru). ArRuzz Media: Yogyakarta. 